\title{
PROPOZYCJA MODELU UZASADNIENIA WARTOŚCI UŻYTKOWEJ PRAC NAUKOWYCH W DZIEDZINIE ZARZĄDZANIA
}

Z a r y s t r e ś c i: Artykuł przedstawia autorską propozycję modelu uzasadniania wartości użytkowej prac naukowych z zakresu nauk o zarządzaniu. Punktem wyjścia dla opracowywanego modelu były modele Szablon Modelu Biznesowego (Business Model Canvas) Alexa Osterwaldera oraz Lean Canvas Asha Maurya.

S ło w a k 1 u c z o w e: zarządzanie, praca naukowa, wartość użytkowa

K 1 a s y f i k a c j a JEL: M13

\section{WSTEPP}

Wychodząc od zawodowego zainteresowania problematyką zarządczą i inwestycyjną w przedsięwzięciach we wczesnej fazie rozwoju, naturalne stało się oparcie podejmowanych decyzji na uproszczonych modelach, do których nie zawsze możliwe było zbudowanie biznesplanu. Ma to istotne znaczenie w zakresie zarządzania strategicznego takimi przedsięwzięciami, poczynając od doboru segmentów inwestycyjnych, po horyzonty czasowe i wielkości nakładów, etc. z punktu widzenia inwestorów. To są pomysły najczęściej młodych przedsiębiorców z pomysłem na biznes w segmencie

* Adres do korespondencji: Fabian Siemiatowski, Uniwersytet Ekonomiczny w Poznaniu, Wydział Zarządzania, Katedra Teorii i Organizacji Zarządzania, al. Niepodległości 10,61-875 Poznań, e-mail: fabian.siemiatowski@phd.ue.poznan.pl; 
nowych technologii. W celu właściwego zweryfikowania ich pomysłu w kontekście własnego doświadczenia i potencjału rynku autor postanowił sięgnąć po modele, które jak się okazuje standardowo wykorzystuje się w tzw. „społecznościach start-up'owych”. Najpopularniejsze modele, pozwalające opisać w prosty sposób pomysły na biznes w segmencie nowych technologii to Business Model Canvas oraz Lean Canvas. Oba modele to proste szablony modeli biznesowych, w które przedsiębiorca wpisuje najważniejsze elementy własnego pomysłu na biznes, przechodząc od posiadanych zasobów, docelowych rynków, po kalkulacje kosztów i ustalenie źródeł przychodów. Cały obraz zaprezentowany na szablonie to model biznesowy danego przedsięwzięcia.

Jednocześnie w praktyce zawodowej autor spotyka opracowania młodych naukowców, którzy także chcieliby skomercjalizować własne nowatorskie pomysły. Warto zatem postawić pytanie, czy opracowania (badania naukowe w dziedzinie zarządzania), w tym przede wszystkim doktoraty (we wstępnej fazie kreowania pomysłu), nie powinny wpisywać się w koncepcję zbliżoną do wspomnianych start-up'ów, dzięki czemu w prosty sposób naukowiec mógłby określić użytkową wartość (propozycję wartości) własnego pomysłu. Ponieważ specyfika wspomnianych wyżej modeli (będą opisywane w dalszej części opracowania) nie spełnia w ocenie autora wymogów specyficznych dla prac naukowych, w niniejszym opracowaniu zaproponowano adaptację szablonu modelu biznesowego, właśnie dla prac naukowych, w kierunku określenia ich wartości użytkowej.

Jak wynika $\mathrm{z}$ analizy literatury $\mathrm{w}$ zakresie modeli biznesowych jednym z obszarów badawczych, które od zarządzania strategicznego będą wymagały głębszego lub nowego poznania, jest modelowanie biznesowe w innowacyjnych gospodarkach. Sienfield i współautorzy [Sinfield i in. 2012, s. 90] postrzegają umiejętność eksperymentowania z nowymi modelami biznesowymi jako ważną kompetencję przedsiębiorstwa, które chce konkurować w zakresie innowacyjności. Casadesus-Masanell i Ricart [za: Moszoro, Gadomska-Lila 2012, s. 99] podkreślają, że trudne warunki funkcjonowania współczesnych przedsiębiorstw będą powodowały, iż coraz częściej będą zmieniały się modele biznesowe, w tym będą powstawały innowacyjne modele biznesowe. Szczególnie będzie to dotyczyło przedsięwzięć związanych z nowymi technologiami i efektami badań badawczo-rozwojowych [Moszoro 2012, s. 99].

Niniejsze opracowanie ma charakter autorskiej propozycji zastosowania szablonu modelu biznesowego do określenia użytkowej wartości prac 
badawczych. Na zainteresowanie się autora tym tematem złożyły się następujące kwestie:

- sfera zawodowej aktywności, związanej m.in. z przedsięwzięciami typu start-up, w tym współpraca w przedsięwzięciach z doktorantami;

- programy finansowania badań naukowych i innowacji w Unii Europejskiej (Horyzont 2020) [nauka.gov.pl];

- własne doświadczenia (bieżące) z pracą nad problematyką badawczą w dziedzinie zarządzania.

Punktem wyjścia rozważań i opracowania autorskiego modelu biznesowego pracy naukowej były opracowania i zastosowania narzędzi:

- Szablon Modelu Biznesowego (Business Model Canvas) Alexa Osterwaldera,

- Lean Canvas Asha Maurya,

- praca nad własnym konspektem pracy doktorskiej, która skłoniła do rozważań nad tematyką użyteczności prac badawczych w dziedzinie zarządzania.

Powyższej wspomniane modele stosują m.in. inwestorzy i przedsiębiorcy, oceniając pomysły oraz sposoby zarządzania przedsięwzięciami w tzw. fazie „seed”, typu start-up, czyli o bardzo wysokim ryzyku powodzenia, na bardzo wczesnym etapie, jeszcze przed realizacją, jednocześnie z bardzo wysoką niepewnością powodzenia biznesu. Pozwalają jednak w prosty sposób ocenić spójność wizji pomysłodawców. Wskazane powyżej modele mają zastosowanie do przedsięwzięć typowo biznesowych, nie precyzują problematyki prac naukowych (badawczych). Autorowi niniejszego opracowania posłużyły jako baza do zbudowania własnej koncepcji szablonu, z wykorzystaniem zagadnień istotnych z punktu widzenia pracy naukowej. Propozycja została przedstawiona w końcowej części opracowania.

\section{KONCEPCJA MODELU BIZNESOWEGO - RYS HISTORYCZNY}

Według B. Nogalskiego [Nogalski 2009, s. 34] modele biznesowe, traktowane jako innowacyjne narzędzia, mogą zwiększać zakres poznania naukowego i sprzyjać praktycznym rozwiązaniom problemów zarządzania strategicznego przedsiębiorstw. Zauważa on jednocześnie, że problematyka modeli biznesowych może stać się, ,priorytetem w naukowym rozpoznaniu rzeczywistości i stanowić może cenną pomoc jaką nauki o zarzadzaniu 
mogą zaoferować dla współczesnych - zwłaszcza polskich - przedsiębiorstw" [Nogalski 2009, s. 35]. W. Rudny dodaje [Rudny 2012, s. 249], że „układ połączeń i powiązań przyczynowo-skutkowych pomiędzy poszczególnymi składowymi modelu biznesu powinien pozwalać na realizację założonych celów przedsiębiorstwa. Architektura modelu biznesu powinna być elastyczna, sprzyjająca jego modyfikacjom i innowacyjności”.

W ostatnich latach wzrosło znaczenie modeli biznesowych. R. Amit, C. Zott, L. Massa [Amit, Zott, Massa 2011] przeprowadzili badania dotyczące lat 1975-2009 związane z publikacjami na temat modeli biznesowych. Wyniki badań prezentuje rysunek nr 1 .

Business Model Articles in the Business/Management Field

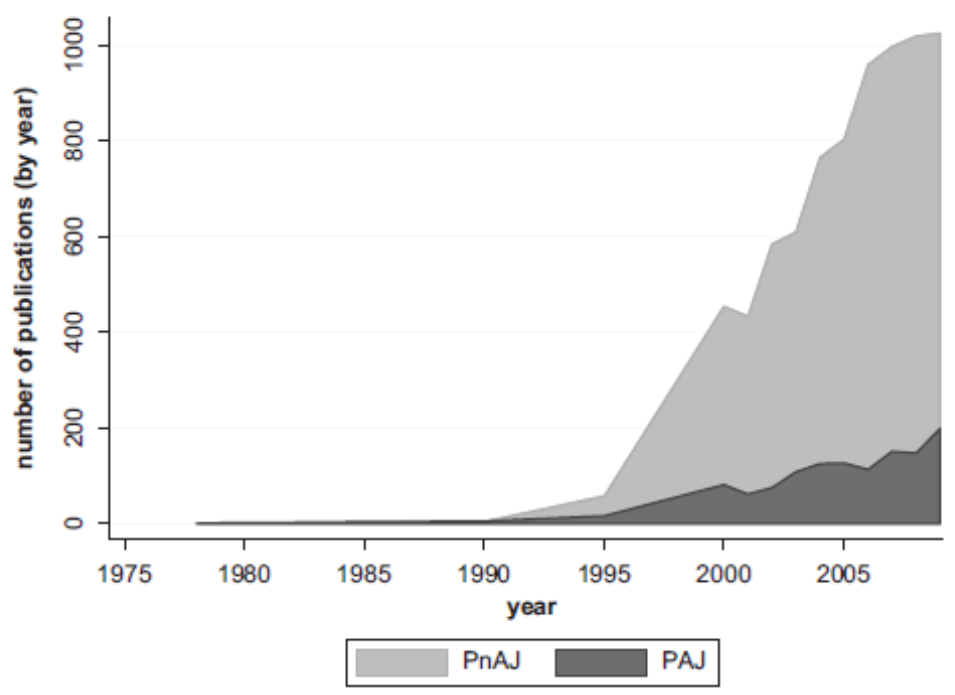

Note: This area graph shows trends in the number of business model articles. PnAJ $=$ articles published in nonacademic journals; PAJ = articles published in academic journals.

Source: Business Source Complete, EBSCOhost database, January 1975-December 2009.

Rysunek 1. Wyniki badań R. Amit, C. Zott, L. Massa na temat publikacji o modelach biznesowych w latach 1975-2009

Źródło: Amit R., Zott C., Massa L., 2011, The Business Model: Recent Developments and Future Research, ,Journal of Management”, Vol. 20, No. 10/2011, s. 5. 
Z rysunku 1 wynika, że od roku 1995 nastąpił gwałtowny wzrost zainteresowania modelami biznesowymi, co wynika z liczby opracowań z tego zakresu, zarówno wśród publikacji naukowych, jak i nienaukowych.

Wśród publikacji naukowych badania dotyczące modeli biznesowych skupiały się głównie na sześciu elementach [Konieczna 2012, s. 110]: tworzeniu definicji, identyfikacji składników, konstruowaniu typologii, przedstawianiu narzędzi do wizualizacji, formułowania wytycznych oraz określaniu kryteriów oceny modeli biznesowych.

Autorzy zajmujący się problematyką modeli biznesowych zauważają, że model biznesowy nie ma jednoznacznej definicji [por. Nogalski 2009, Nogalski, Szpitter, Kreft 2010, Konieczna 2013, Konieczna 2012, Rudny 2012]. Analizy dokonane przez I. Konieczną [Konieczna 2013, Konieczna 2012] wskazują, że najczęściej definicje modelu biznesowego nawiązują do „wyborów strategicznych, tworzenia wartości, przechwytywania wartości oraz sieci wartości”. Wśród wybranych przez I. Konieczną definicji modelu biznesowego pojawiają się w ogólnym ujęciu:

- K. Obłója - model biznesowy stanowi odniesienie do tego, co firma planuje robić, żeby konkurować na rynku, jakie posiada zasoby i kompetencje do podtrzymania pozycji konkurencyjnej i jak skonstruowany jest jej łańcuch wartości;

- P. Timmersa, który definiuje model biznesowy jako ,architekturę dla produktu, usługi i przepływu informacji” wraz z opisem ról i ,aktorów biznesowych", korzyści i źródeł dochodu;

- B. Mahadevan - model biznesowy to trzy strumienie (wartości do partnerów biznesowych, dochodów i strumień logistyczny);

- M. Rappa - model biznesowy to metoda prowadzenia działalności gospodarczej, pozwalająca generować przychody;

- R. Amite'a i C. Zott'a - model biznesowy przedstawia istotę, strukturę i sposób zarządzania transakcjami w celu stworzenia wartości poprzez wykorzystanie szans;

- L. Dogonova i M. Eygum-Renault - dokonują rozważań na temat modelu biznesowego z trzech punktów widzenia: esencjalistycznego (opis rzeczywistości poza modelem), funkcjonalnego (przewidują przyszłe przedsięwzięcia i tworzenie wartości) i pragmatycznego (rynkowe urządzenia kalkulacji i podejmowania decyzji);

- J. Magrett - modele biznesowe pokazują, jak działa firma, logika ekonomiczna dostarczania wartości przy optymalnym poziomie kosztów; 
- M. Morris'a, M. Schindehutte i J. Allen'a - modele biznesowe, to krótkie przedstawienie powiązań decyzji i przewagi konkurencyjnej;

- A. Afuah i C.L. Tucci - model biznesowy jako metoda powiększania i wykorzystywania zasobów w celu przedstawienia oferty, której wartość przewyższa wartość konkurencji i zapewnia firmie dochodowość;

- R. Casadesus-Masanell i J.E. Ricard - na model biznesowy składają się wybory i ich konsekwencje;

- D. Tapscott'a - modele biznesowe przedstawiają, jak firma wykorzystuje wszystkie odpowiednie środki do tworzenia zróżnicowanej wartości;

- A. Osterwaldera i Y. Pigneur - model biznesowy to koncepcyjne narzędzie zawierające zestaw elementów i ich relacji, wyrażające logikę biznesową - ta koncepcja jest przedmiotem analizy w dalszej części opracowania.

Niezależnie od przyjętej definicji modelu biznesowego, który może stanowić istotne wsparcie dla procesu tworzenia strategii, należy zwrócić uwagę na mogące pojawić się problemy, mające wpływ na tworzenie i wykorzystywanie tych modeli [Rudny 2012, s. 253]:

- błędne założenia bazowej logiki,

- ograniczenie wyborów strategicznych w modelu,

- brak odpowiedniego zrozumienia procesów tworzenia i zatrzymania wartości,

- błędne założenia dotyczące tworzenia sieci wartości.

\section{KONCEPCJE MODELU BIZNESOWEGO OSTERWALDERA I MUARYA}

Alexander Osterwalder definiuje model biznesowy jako opis przesłanek stojących za sposobem, w jaki organizacja tworzy wartość i zapewnia z niej zyski [Osterwalder i Pigneur 2012, s. 18]. Uważa, że odpowiednie ujęcie modelu pozwala prowadzić produktywne dyskusje dla wszystkich potencjalnie zainteresowanych zagadnieniem, którego dany model dotyczy. W przekonaniu Osterwaldera i Pigneura [Osterwalder i Pigneur 2012, s. 19] model biznesowy składa się z dziewięciu elementów, które wpisują się w logikę zarabiania przez przedsiębiorstwo pieniędzy. Dziewięć wspomnianych elementów obejmuje cztery zasadnicze obszary funkcjonowania: klientów, oferty, zasoby i pozycję finansową. Model biznesowy jest 
szkicem strategii. Szablon modelu Osterwaldera został przedstawiony na rysunku 2.

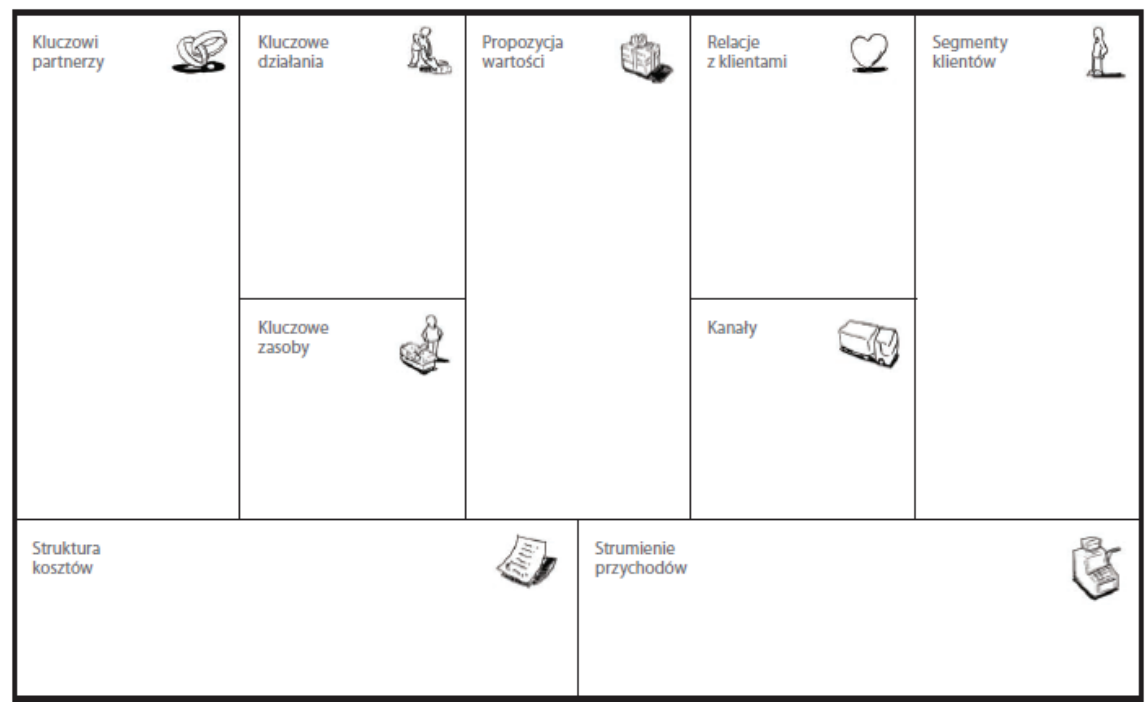

Rysunek 2. Szablon modelu biznesowego Osterwaldera

Źródło: Za: Osterwalder A., Pigneur Y., Tworzenie modeli biznesowych. Podręcznik wizjonera, Gliwice 2012, Helion (Onepress), s. 48.

Interpretacja poszczególnych elementów modelu Osterwaldera została przedstawiona w tabeli 1 .

Na podstawie szablonu modelu biznesowego Osterwaldera, Ash Maurya zaproponował model Lean Canvas [leanstack.com]. Lean Canvas jest szablonem modelu biznesowego dostosowanym do przedsięwzięć typu start-up, czyli nowo zakładanych przedsiębiorstw o wysokiej niepewności odniesienia sukcesu. Metoda Lean Canvas proponuje iteracyjne podejście do zarządzania procesem. Umożliwia to szybkie reagowanie twórców na zmiany otoczenia, w celu budowania wartości dla właścicieli. Ash Maurya dostosował szablon modelu do potrzeb przedsiębiorcy, zmieniając te pola, które lepiej oddawały potrzeby rozpoczynających prace nad nowym produktem/projektem. 


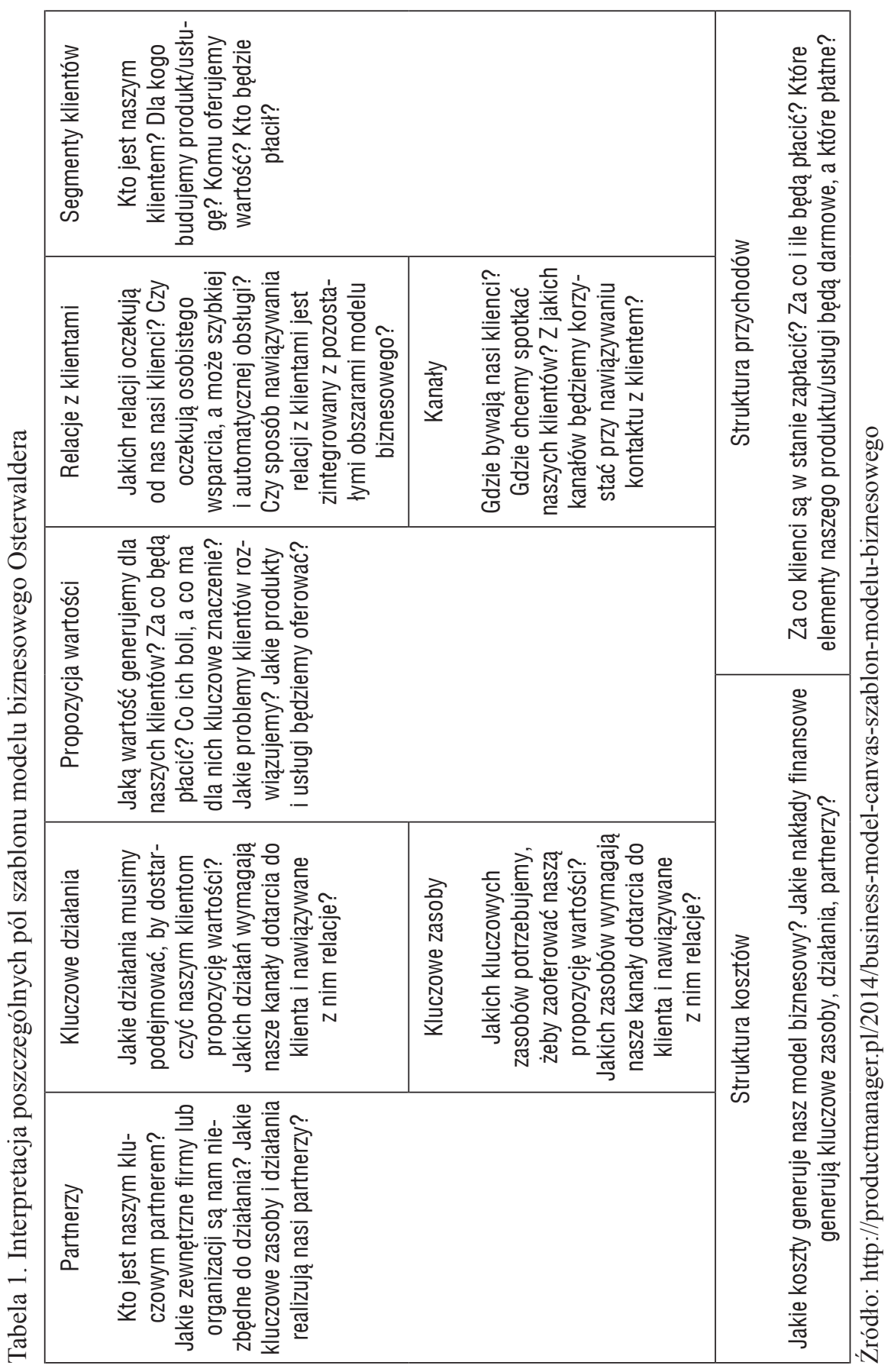


Różnice pomiędzy modelem Osterwaldera a Maurya zostały zaprezentowane w tabeli 2 .

Tabela 2. Różnice pomiędzy szablonem modelu biznesowego Osterwaldera oraz Lean Canvas Maurya

\begin{tabular}{|l|l|l|}
\hline \multicolumn{1}{|c|}{ Czynnik } & \multicolumn{1}{|c|}{ Model Osterwaldera } & \multicolumn{1}{c|}{ Model Maurya } \\
\hline Cel & Nowe i istniejące przedsiębiorstwa & $\begin{array}{l}\text { Wyłącznie dla nowo zakładanych } \\
\text { przedsiębiorstw (start-up) }\end{array}$ \\
\hline $\begin{array}{l}\text { Przeznaczenie } \\
\text { modelu }\end{array}$ & $\begin{array}{l}\text { Klienci, inwestorzy, przedsiębiorcy, } \\
\text { konsultanci, doradcy }\end{array}$ & Przedsiębiorcy \\
\hline $\begin{array}{l}\text { Podejście do } \\
\text { klienta }\end{array}$ & $\begin{array}{l}\text { Kładzie nacisk na segmenty klien- } \\
\text { tów, kanałów i relacji z klientami }\end{array}$ & $\begin{array}{l}\text { Nie kładzie dużego nacisku na } \\
\text { segmenty klientów, ponieważ } \\
\text { nie ma gotowego produktu }\end{array}$ \\
\hline $\begin{array}{l}\text { Podejście } \\
\text { do budowy } \\
\text { modelu }\end{array}$ & $\begin{array}{l}\text { Określa zasoby, charakter i źródła } \\
\text { finansowania oraz przewidywane } \\
\text { źródła przychodów }\end{array}$ & $\begin{array}{l}\text { Przede wszystkim problem } \\
\text { i propozycje jego rozwiązania, } \\
\text { koszty z tym związane oraz } \\
\text { przychody }\end{array}$ \\
\hline $\begin{array}{l}\text { Konkurencyj- } \\
\text { ność }\end{array}$ & $\begin{array}{l}\text { Koncentruje się na propozycji } \\
\text { wartości w wymiarze ilościowym } \\
\text { i jakościowym, jako metoda pozo- } \\
\text { stania na rynku }\end{array}$ & $\begin{array}{l}\text { Ocenia przewagi konkurencyjne } \\
\text { oraz to, jak je wykorzystać do } \\
\text { lepszego osadzenia na rynku }\end{array}$ \\
\hline Użytek modelu & $\begin{array}{l}\text { Sprzyja zrozumieniu, kreatywności, } \\
\text { dyskusji i analizie konstruktywnej }\end{array}$ & $\begin{array}{l}\text { Proste rozwiązanie problemu, } \\
\text { umożliwiające przedsiębiorcy } \\
\text { podejście iteracyjne do zarzą- } \\
\text { dzania }\end{array}$ \\
\hline
\end{tabular}

Źródło: na podstawie: https://canvanizer.com/how-to-use/business-model-canvas-vs-lean-canvas

Zmiany zaproponowane przez Mauraya, zostały przedstawione na rysunku 3. 


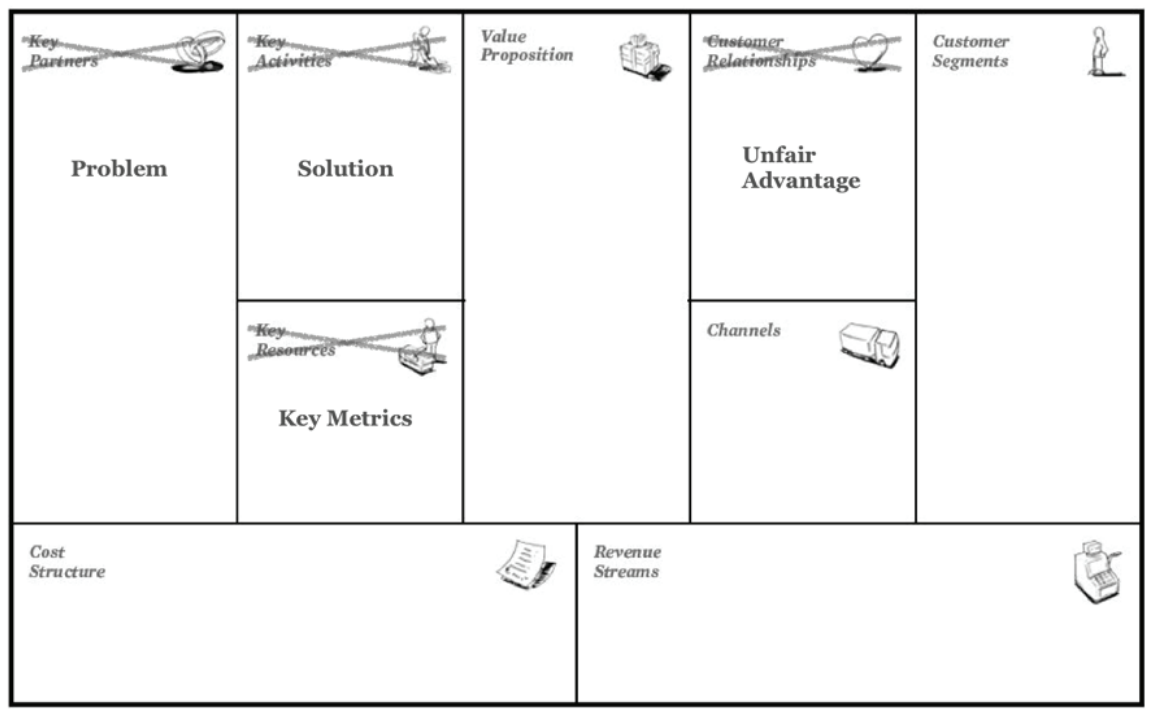

Rysunek 3. Zmiany w szablonie modelu biznesowym wprowadzone przez Mauraya

Źródło: http://leanstack.com/why-lean-canvas/

Szablon modelu Maurya został przedstawiony na rysunku 4. Ash Maurya proponuje następujący sposób podejścia do wypełniania poszczególnych pól szablonu [leanstack.com]:

- Problem - wskazanie trzech głównych problemów przedsiębiorcy $\mathrm{w}$ danym momencie,

- Rozwiązanie - zaproponowanie trzech sposobów rozwiązania problemów,

- Mierniki - wymienienie podstawowych mierników sukcesu związane $\mathrm{z}$ rozwiązaniem problemu,

- Propozycja wartości - wskazanie powodów, dla których przedsiębiorca różni się od konkurencji i wart jest uwagi,

- Przewaga konkurencyjna - powody, które sprawiają, że pomysł nie może być łatwo skopiowany; bariery wejścia,

- Kanały - kanały dotarcia z produktem do klientów,

- Segmenty klientów - segmenty docelowe, dla których produkt może być oferowany,

- Koszty - koszty rozwiązania problemów i osiągniecia wymaganych mierników oraz dotarcia do klientów,

- Przychody - model przychodowy, marże brutto, źródła przychodów. 


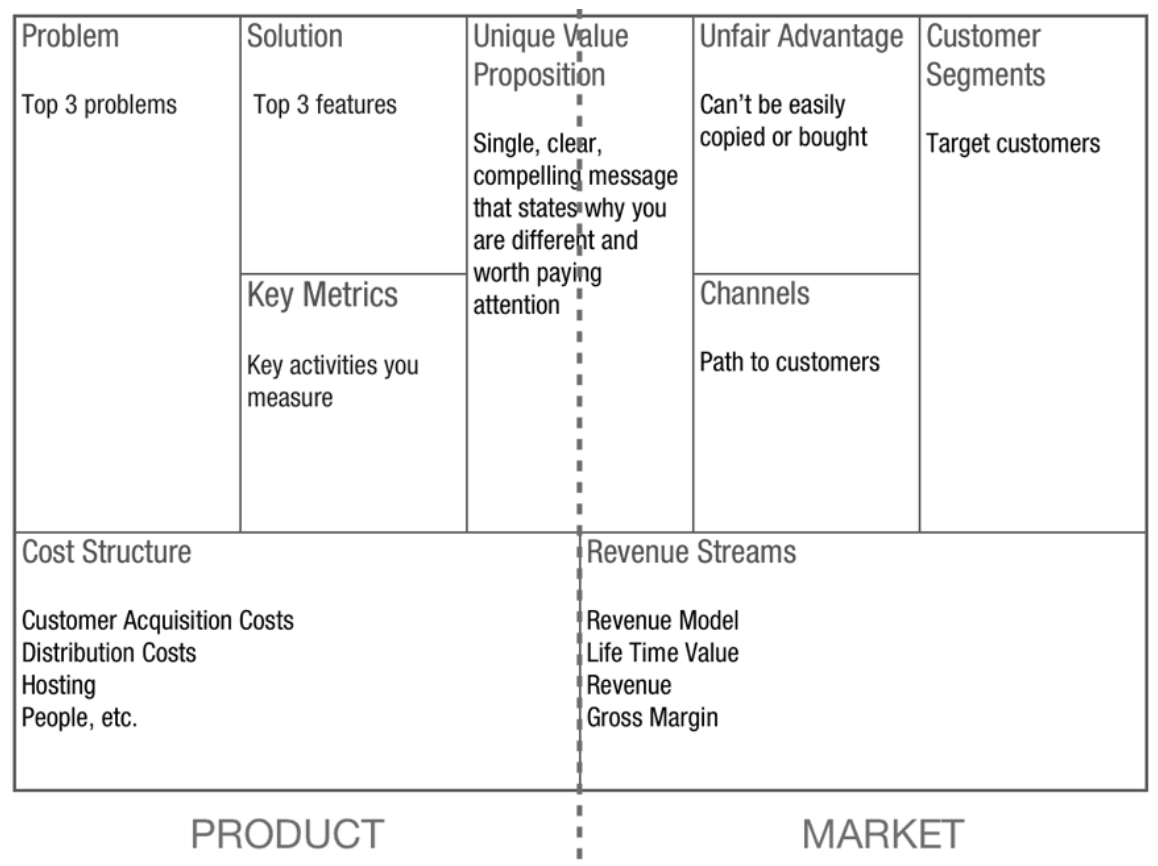

Lean Canvas is adapted from The Business Model Canvas (http://www.businessmodelgeneration.com) and is licensed under the Creative Commons Attribution-Share Alike 3.0 Un-ported License.

Rysunek 4. Szablon modelu Lean

Źródło: http://leanstack.com/why-lean-canvas/

Tak sformułowany model biznesowy dla nowych przedsięwzięć wywołał $\mathrm{u}$ autora refleksję i skłonił do dalszej pracy w celu zaproponowania autorskiego podejścia do wykorzystania modelu na potrzeby pracy nad własną dysertacją, pod kątem użyteczności wiedzy naukowej w dziedzinie zarządzania.

\section{PRACA NAUKOWA I JEJ WARTOŚĆ UŻYTKOWA}

W dzisiejszych czasach praca naukowa w dziedzinach ekonomii i zarządzania, skupia się m.in. na opisie zjawisk, powodach tych zjawisk i modelach możliwych do implementacji w realnej gospodarce. Wiedza o zarządzaniu, zdaniem autora, powinna więc mieć charakter użytkowy. Dlatego już na etapie ustalania koncepcji, wyboru tematu i problematyki pracy naukowej 
powinno się usystematyzować ów wybór. Dlatego wydaje się zasadna próba przyrównania pracy doktoranta z działaniami założycieli start-up'ów.

Tak zwany start-up'owiec (lub grupa) staje przede wszystkim przed problemem określenia „modelu biznesowego”. Dla tego dość nowego segmentu (społeczności start-up) zostały już wypracowane modele wspomagające budowanie prostych strategii i modeli biznesowych. Opierające się na strukturze szablonu modelu zaproponowanego przez Osterwaldera, w prosty sposób ujmują na jednym arkuszu wszystkie 9 wymiarów modelu biznesowego. Pozwalają potencjalnym inwestorom lub odbiorcom idei łatwo zapoznać się ze spójnością wizji pomysłodawców start-up i szybko podjąć decyzję o inwestycji.

Nauce obecnie poświęca się wiele miejsca, włączając w to inicjatywy związane z finansowaniem badań naukowych (np. Horyzont 2020). Ideą przyświecającą finansującym jest implementacja rozwiązań naukowych do gospodarki. Istotne są różne poziomy tzw. gotowości technologicznej produktów. Ogólne określenie „produkty” dotyczy też procesów innowacyjnych form rozwiązania problemów, np. zarządzania procesami. Wydaje się zachodzić więc pewna analogia pomiędzy inicjatywami typu start-up o niskich poziomach TRL ${ }^{1}(1-3)$ z opracowaniem naukowym. Doktoratowi można przypisać poziomy od 1 do 3 TRL, z czego poziom 1 to będzie pomysł, a poziom 3 napisany doktorat. Przedmiotem zainteresowania w niniejszym opracowaniu są najniższe poziomy TRL, czyli pomysłu na pracę naukową, który jeszcze nie został napisany - w celu uzasadnienia użyteczności pomysłu na pracę naukową.

Przedsięwzięcia start-up dopracowały się modeli zarządzania. Przykładem takiego rozwiązania, np. dla aplikacji internetowych, jest model wcześniej opisywany Lean Canvas (Maurya). Lean Canvas jest pochodną Modelu Biznesowego Osterwaldera. Najważniejszą cechą obu modeli jest ich prostota uchwycenia wszystkich istotnych zagadnień na jednym szablonie.

Skala stosowana przez NCBIR (opierająca się o doświadczenia NASA), dotycząca oceny poziomu technologicznej gotowości produktu do wdrożenia http://www. ncbir.pl/aktualnosci/art,2313,poziomy-gotowosci-technologicznej.html 


\section{AUTORSKA KONCEPCJA MODELU BIZNESOWEGO DLA PRACY NAUKOWEJ}

Na potrzeby niniejszego opracowania, została dokonana próba przeniesienia idei szablonu Osterwaldera na uzasadnienie użyteczności badań naukowych. Punktem wyjścia (wyjściowa refleksja) była modyfikacja zaproponowana przez Asha Maurya (jako podejście do modelu w sposób dynamiczny), polegająca na dostosowaniu modelu Osterwaldera (modelu statycznego) do potrzeb zarządzania iteracyjnego przedsięwzięciami o niskim poziomie TRL (gotowości technologicznej). Analogicznie jak oba modele, model autorski ma identyczną strukturę, zmianie ulegają poszczególne pola szablonu, dostosowane do potrzeb wynikających z podstaw pracy naukowej, takich jak określenie problemu badawczego, określenie celów, a także określenie właściwej metody badawczej. Takie ujęcie pozwala na uproszczoną „walidację” koncepcji od strony „spójności” naukowej, a jednocześnie dzięki pozostałym polom na ocenę jej użyteczności. Model szablonu autorskiego ma służyć pomysłom na pracę naukową, a niekoniecznie gotowym doktoratom. Ma odpowiadać na pytanie o słuszność koncepcji w kontekście użyteczności uzyskanej wiedzy. Gotowe doktoraty, zdaniem autora, jeżeli zachodziłaby taka potrzeba, mogą wpisywać się w modele Osterwaldera i Maurya.

W tabeli nr 3 została zaprezentowana, w najprostszy sposób, autorska propozycja ujęcia użytkowej wartości badań naukowych. Wskazana została także kolejność wypełniania pól (zoperacjonalizowanie narzędzia), umożliwiające dojście do finalnego elementu, jakim są korzyści (użyteczność) płynące z planowanej pracy naukowej.

Opis poszczególnych pól tabel według kolejności wypełniania:

- Pole 1 - „Problem badawczy” - co zostało zaobserwowane w życiu gospodarczym, co będzie problemem badawczym, jakie zjawisko w życiu gospodarczym należy zbadać i zaproponować rozwiązanie?

- Pole 2 - „Odbiorcy” - Kogo to zjawisko dotyczy, gdzie w rzeczywistości gospodarczej zaobserwowano badane zjawisko, czy zwrotnymi odbiorcami wyników badania będą podmioty, u których zaobserwowano zjawisko?

- Pole 3 - „Cele” - Jakie są cele do osiągnięcia związane z badanym problemem? Będzie to miało fundamentalne znaczenie dla określenia wartości dla gospodarki. 


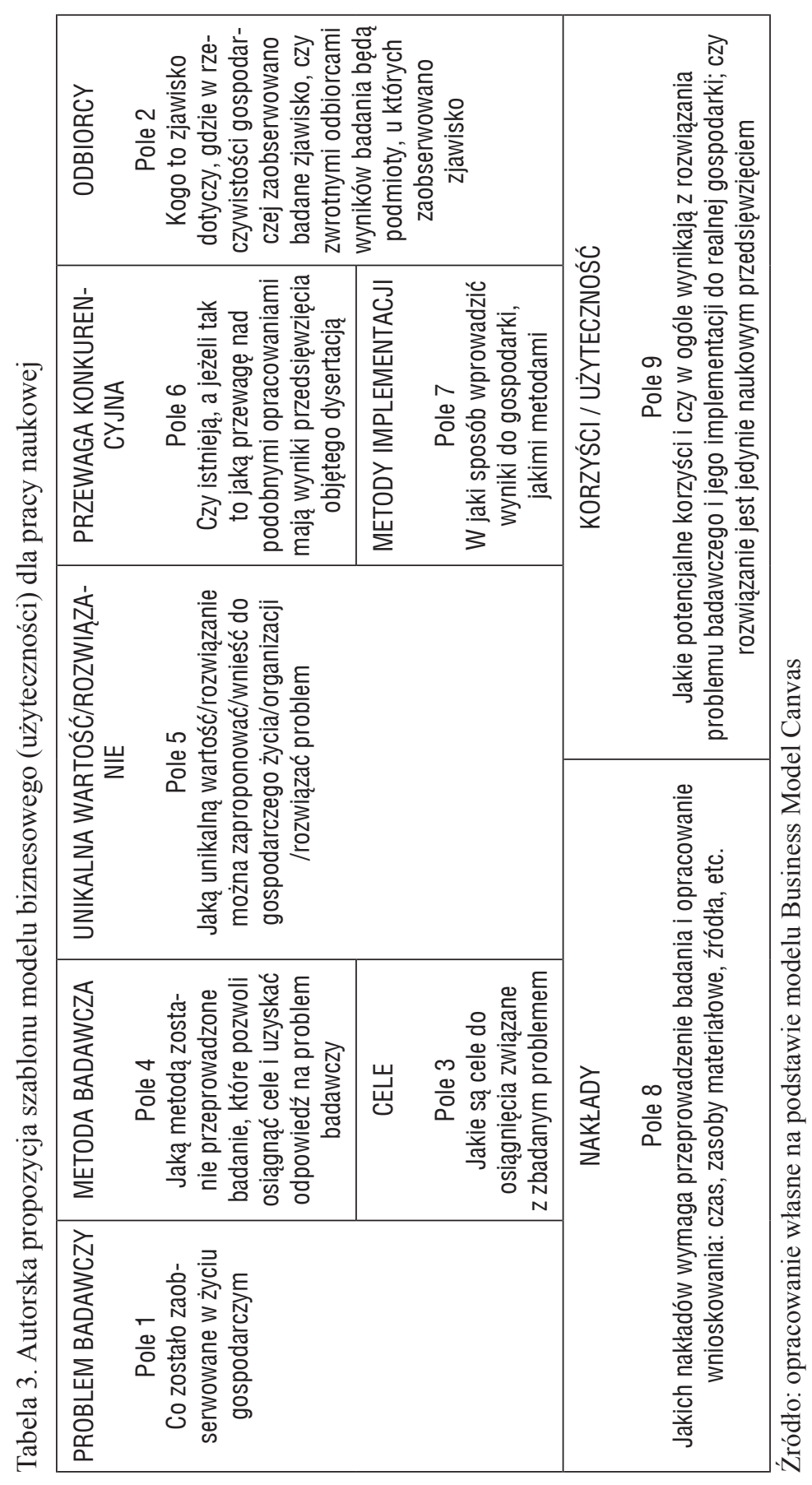


- Pole 4 - „Metoda badawcza” - Jaką metodą zostanie przeprowadzone badanie, które uwiarygodni wyniki oraz pozwoli osiągnąć cele i uzyskać odpowiedź na problem badawczy? Właściwy dobór metody w kontekście problematyki modelu biznesowego pracy naukowej.

- Pole 5 - „Unikalna wartość/rozwiązanie” - Jaką unikalną wartość rozwiązania można zaproponować lub wnieść do gospodarczego życia lub do organizacji lub rozwiązać problem? Czemu ma służyć przedsięwzięcie w sensie wartości dla gospodarki?

- Pole 6 - „Przewaga konkurencyjna” - Czy istnieją, a jeżeli tak, to jaką przewagę nad podobnymi opracowaniami mają wyniki przedsięwzięcia objętego dysertacją? Analiza konkurencji w danym obszarze, znajomość otoczenia konkurencyjnego.

- Pole 7 - „Metoda implementacji” - W jaki sposób wprowadzić wyniki do gospodarki, jakimi metodami? Czy rozwiązanie jest dedykowane, czy może mieć szerokie zastosowanie dla gospodarki. Publikacje, szkolenia, konferencje, itp.

- Pole 8 - „Nakłady” - Jakich nakładów wymaga przeprowadzenie badania i opracowanie wnioskowania: czas, zasoby materiałowe, źródła, etc.? W kontekście rozwiązywanego problemu badawczego, istotne jest także to, że nakłady mogą być wyższe niż możliwe do uzyskania efekty gospodarcze, jeżeli np. badanie może dostać wsparcie z programów wspierających naukowców.

- Pole 9 - „Korzyści / użyteczność” - Jakie potencjalne korzyści i czy w ogóle wynikają z rozwiązania problemu badawczego i jego implementacji do realnej gospodarki; czy rozwiązanie jest jedynie naukowym przedsięwzięciem? Możliwe uwzględnienie dofinansowania, jeżeli przedsięwzięcie ma charakter czysto naukowy, rozwiązujący problem na potrzeby np. innych nauk.

Modyfikacja modelu Osterwaldera i Maurya to przede wszystkim lewa strona arkusza. Autorska modyfikacja związana jest przede wszystkim z ujęciem w modelu problematyki badawczej jako działań podlegających modyfikacjom - ujęcie dynamiczne, tożsame z podejściem Maurya. Zostały tu zaprezentowane podstawowe cechy pracy naukowej. Prawa strona tabeli, tożsama z modelami Osterwaldera i Mauraya, stanowi jej aspekt użytkowy w sensie gospodarczym - odbiorcy. Dół tabeli to nakłady konieczne do poniesienia na pracę naukową i dotarcie do gospodarki oraz korzyści $\mathrm{z}$ utylitarnego charakteru wykonanej pracy. 
W tabeli 4 zostały zaprezentowane porównawczo poszczególne pola szablonów Osterwaldera, Maurya i autorskiego z dodatkowym opisem do podejścia w tym ostatnim szablonu.

Tabela 4. Porównanie poszczególnych pól trzech szablonów modeli biznesowych

\begin{tabular}{|c|c|c|c|}
\hline $\begin{array}{l}\text { Model Osterwal- } \\
\text { dera }\end{array}$ & Model Maurya & Autorski model & $\begin{array}{c}\text { Opis dotyczący autorskiego } \\
\text { modelu }\end{array}$ \\
\hline Partnerzy & Problem & $\begin{array}{l}\text { Problem } \\
\text { badawczy }\end{array}$ & $\begin{array}{l}\text { Problem natury naukowej } \\
\text { w odróżnieniu od problemów } \\
\text { bieżących rozwiązywanych } \\
\text { przez start-up'y }\end{array}$ \\
\hline $\begin{array}{l}\text { Kluczowe } \\
\text { działania }\end{array}$ & Rozwiązanie & $\begin{array}{c}\text { Metoda } \\
\text { badawcza }\end{array}$ & $\begin{array}{c}\text { Uznana metoda naukowa, } \\
\text { dla rozwiazzania problemu } \\
\text { naukowego }\end{array}$ \\
\hline Kluczowe zasoby & Mierniki & Cele & Cele o wymiarze naukowym \\
\hline Wartość & Unikalna wartość & Unikalna wartość & $\begin{array}{l}\text { Wartość tożsama pomiędzy } \\
\text { modelami }\end{array}$ \\
\hline $\begin{array}{l}\text { Relacje z klien- } \\
\text { tami }\end{array}$ & $\begin{array}{l}\text { Przewaga konku- } \\
\text { rencyjna }\end{array}$ & $\begin{array}{c}\text { Przewaga } \\
\text { konkurencyjna }\end{array}$ & $\begin{array}{l}\text { Przyjęta przewaga konkuren- } \\
\text { cyjna nad innymi potencjal- } \\
\text { nie opracowaniami o podob- } \\
\text { nej problematyce nadawczej }\end{array}$ \\
\hline $\begin{array}{c}\text { Kanały } \\
\text { dystrybucji }\end{array}$ & Kanały & $\begin{array}{l}\text { Metoda } \\
\text { implementacji }\end{array}$ & $\begin{array}{l}\text { Metoda dotarcia do odbior- } \\
\text { ców w gospodarce }\end{array}$ \\
\hline Segment rynku & $\begin{array}{l}\text { Segment } \\
\text { klientów }\end{array}$ & Odbiorcy & $\begin{array}{l}\text { Tożsame pomiędzy } \\
\text { modelami }\end{array}$ \\
\hline Koszty & Koszty & Nakłady & $\begin{array}{l}\text { Nakłady, pole praktycznie } \\
\text { tożsame pomiędzy modelami }\end{array}$ \\
\hline Przychody & Przychody & Korzyści & $\begin{array}{c}\text { Korzyści (użyteczność) także } \\
\text { o wymiarze jakościowym, } \\
\text { ponieważ istnieje możliwość } \\
\text { działania non-profit w bada- } \\
\text { niach naukowych }\end{array}$ \\
\hline
\end{tabular}

Źródło: opracowanie własne. 


\section{PODSUMOWANIE}

Opracowanie miało na celu zaproponowanie autorskiego szablonu modelu biznesowego dla pracy naukowej, jako nowego obszaru badawczego w zarządzaniu strategicznym. Wychodząc od problematyki modeli biznesowych, jako kierunku cieszącego się szczególnym zainteresowaniem gospodarek innowacyjnych, poprzez próbę definicji modelu biznesowego, wybór najbardziej odpowiedniej definicji i rozwiązania do dalszych prac, autor zaproponował narzędzie modelowania biznesowego (użyteczność) pracy naukowej. Rozwiązanie bazuje na dwóch modelach, z czego jeden jest pierwotny. Pierwotny model, który posłużył do dalszych prac to szablon modelu biznesowego Osterwaldera (Model Biznesowy Canvas). Model Osterwaldera został zmodyfikowany przez A. Maurya na potrzeby przedsięwzięć o niskim poziomie gotowości technologicznej (niskie TRL, co oznacza wysoki poziom ryzyka inwestycyjnego, są to przedsiębiorstwa typu start-up). Praca doktorska odpowiada przedsięwzięciom o niskim poziomie TRL (1-3) i jednocześnie powinna stanowić użyteczną wartość dla gospodarki. Współczesne (bieżące) modele finansowania z programów unijnych (Horyzont 2020) przewidują finansowanie prac naukowych badawczo-rozwojowych, podchodząc do nich jak do rozwiązań innowacyjnych (współfinansowania inwestorów prywatnych i funduszy wspierających). W tym rozumieniu, według autora, praca naukowa staje się przedsięwzięciem użytkowym, które wymaga zamodelowania biznesowego. Takim modelem mogą być zainteresowani m.in. prywatni inwestorzy, którzy wierząc w skuteczność i efektywność pracy naukowej (co powinno wynikać z szablonu modelu biznesowego pracy naukowej) modelu, mogą zdecydować się np. na inwestycję w dalsze prace lub implementację. Przede wszystkim jednak, wydaje się, że dopiero uzyskanie kompletnego i spójnego obrazu modelu biznesowego, potwierdzającego użyteczność planowanej do uzyskania wiedzy, uzasadnia podjęcie pracy nad pracą naukową w dziedzinie zarządzania. Z tego też powodu, zdaniem autora, jest to ciekawy i nowy obszar badawczy w dziedzinie zarządzania strategicznego, ujmujący świat nauki i przedsiębiorczości w jeden nawias. $Z$ pewnością wymagałby jednak dalszych prac i badań, potwierdzając zasadność koncepcji. 


\section{LITERATURA}

Amit R., Zott C. , Massa L., (2011), The Business Model: Recent Developments and Future Research, „Journal of Management”, Vol. 20, No. 10/2011.

Konieczna I., (2013), Model biznesowy - kwestia definicji i komponentów, [w:] R. Krupski (red.), Zarzadzanie strategiczne Quo vadis?, Prace naukowe Wałbrzyskiej Wyższej Szkoły Zarządzania i Przedsiębiorczości, Wałbrzych.

Konieczna I., (2012), Rozwój koncepcji modelu biznesowego, „Studia i Prace Kolegium Zarządzania i Finansów” Szkoła Główna Handlowa w Warszawie, Zeszyt Naukowy 116/2012.

Moszoro B., Gadomska-Lila K., (2013), Innowacyjny model biznesowy - kluczowe elementy, „Management and Business Administration. Central Europe”, vol. 21, nr 1(120).

Nogalski B., (2009), Rozważania o modelach biznesowych przedsiębiorstw jako ciekawym poznawczo kierunku badań problematyki zarzadzania strategicznego, [w:] R. Krupski (red.), Zarzadzanie strategiczne. Problemy, kierunki badań, Prace naukowe Wałbrzyskiej Wyższej Szkoły Zarządzania i Przedsiębiorczości, Wałbrzych.

Nogalski B., Szpitter A., Kreft Z., (2010), Zarzadzanie wiedza w organizacji jako czynnik zmian modeli biznesowych, Polskie Stowarzyszenie Zarządzania Wiedzą, Seria: Studia i Materiały, nr 26.

Osterwalder A., Pigneur Y., (2012), Tworzenie modeli biznesowych. Podręcznik wizjonera, Helion (Onepress), Gliwice.

Rudny W., (2012), Model biznesu w procesie tworzenia wartości, „Zarządzanie finansami firm - teoria i praktyka", Prace Naukowe Uniwersytetu Ekonomicznego we Wrocławiu, nr 271/2012.

Sinfield, J., Calder, E., McConnell, B. i Colson, S., (2012), How to Identify New Business Models, MIT Sloan Management Review, vol. $53 \mathrm{nr} 2$.

https://canvanizer.com/how-to-use/business-model-canvas-vs-lean-canvas [dostęp: 2016-01-08]

http://leanstack.com/why-lean-canvas/ [dostęp: 2016-01-08]

http://www.nauka.gov.pl/horyzont-2020/ [dostęp: 2016-01-08]

http://productmanager.pl/2014/business-model-canvas-szablon-modelu-biznesowego/ [dostęp: 2016-01-08]

http://www.ncbir.pl/aktualnosci/art,2313,poziomy-gotowosci-technologicznej. html [dostęp: 2016-01-08] 


\title{
THE CONCEPT OF UTILITY VALUE MODEL FOR THE SCIENTIFIC WORK IN MANAGEMENT SCIENCE
}

\begin{abstract}
The article presents the original concept of a model for justifying the utility value of scientific work in management science. The basis for creating this model were Alex Osterwalder's Business Model Canvas and Ash Mauryas Lean Canvas model.
\end{abstract}

Keywords: management science, scientific work, utility value model 